\title{
Comparative Research on Urban Political Conflict: Policy Amidst Polarization
}

\author{
Scott A. Bollens*
}

Department of Planning, Policy, and Design University of California Irvine, CA 92697-7075, USA

\begin{abstract}
Based on field research in politically contested cities in Europe, Africa, and the Middle East, this paper provides a methodological guide to analyzing urban policy in jurisdictions with multiethnic conflict. It seeks to stimulate the intellectual development of comparative conflict studies by illuminating the issues involved in cross-national urban research in troubled settings of ethnic conflict and fragmentation. It describes why scholars must be clear in articulating the types of cities under study and how a specific analytic "lens" can be used to gain access to wider issues of urban governance and policymaking in divided societies. Key urban ethnic conditions - territoriality/control over land, distribution of economic benefits and costs, access to policy-making, and group identity - are described in terms of how they can facilitate or impede the movement toward peaceful co-existence. The paper positions the "city" not as a unitary actor but one that is internally differentiated and externally linked. A comparative analytic framework ("scaffolding") for cross-national research on urban conflict is then presented. Finally, empirical vignettes from eight contested cities in Spain, the former Yugoslavia, Israel/Palestine, South Africa, Cyprus, and Northern Ireland are provided to highlight how theoretical and conceptual understandings can make sense of case study findings and provide footing for theoretical advances and further case study selection as a multi-city research program continues.
\end{abstract}

Keywords: urban conflict, ethnic/racial divisions, research methodology, comparative case study, urban planning.

\section{INTRODUCTION}

The challenges of cross-national urban research in conflict cities are similar to those that arise in qualitative, case study research generally, but become intensified because there commonly are multiple and antagonistic "realities" in these politically volatile and precarious cities. This paper covers methodological issues I have confronted during approximately 15 years of field research, data collection involving over 220 interviews with political leaders, planners, architects, community representatives, and academics, and the writing of three books [1-3]. In this work, I have emphasized the role of policy and planning in contested urban environments and the effects these urban strategies have on the magnitude and manifestations of ethno-national conflict. Cities that I have investigated are Jerusalem (Israel/Palestine), Belfast, Johannesburg, Nicosia (Cyprus), Sarajevo and Mostar (Bosnia) and Basque cities and Barcelona (Spain). Each of these cities has been, or is, politically contested or polarized, meaning that they are characterized by deep-rooted and often historically based nationalistic group conflict. The existence of competing nationalistic allegiances can lead to violence, instability and can eventually tear a society and the city apart.

This paper endeavors to enhance the intellectual development of the comparative study of urban political conflict by focusing on the methodological issues and challenges of conducting research across diverse settings. Comparative research on contested cities has the potential of increasing our understanding of why some cities are peace promoting

*Address correspondence to this author at the Department of Planning, Policy, and Design University of California Irvine, CA 92697-7075, USA; Tel: 949-824-7696; Fax: 949-824-8566; E-mail: bollens@uci.edu while others experience violence and instability. It helps to identify the contribution of cities to processes of state making, crisis and collapse. This paper describes the use of a conflict-stability continuum as comparative scaffolding for multi-site qualitative research. Locating cities along such a dimensional scale can increase our ability to examine states' capacities to manage conflict across a spectrum rather than through the use of rigid dichotomized categories. The use of a comparative framework further allows for the discovery of crosscutting policy issues that bridge different types of cities or cities at a particular location on the analytical continuum or spectrum. The distillation of such insights increases the relevance of this research for the practitioner and policymaking communities.

This paper first describes why scholars must clearly define the types of cities under study and how a specific analytic "lens" can sharpen analyses of wider issues of urban governance and policymaking in divided societies. Key urban ethnic conditions that are influenced by planning policies are described in terms of how they can facilitate or impede the movement toward peaceful co-existence. The paper then discusses the "city" not as a unitary actor but one that is internally differentiated and externally linked. A comparative analytic framework ("scaffolding") for cross-national research on urban conflict is then presented. Finally, brief summaries of field research findings from eight contested cities are provided to highlight how theoretical and conceptual understandings can make sense of case study findings.

\section{Articulating City Types}

In order to make valid generalizable statements based on comparative research, we must be as clear as possible about what types of cities we are studying. Labels such as "divided", "polarized", "contested", "violent" must not be used 
without clear definitions. Each of these terms allude to difficult urban circumstances, but they place emphases on differing dimensions along which cities, and their societies, can fragment. In addition, some terms are used to describe different environments at different times. For example, cities are described as "divided" in numerous contexts, including North American and western European cities segregated by race, ethnicity, and class. At other times, "divided" alludes to more extreme circumstances of political division and contestation. Further thickening the definitional quagmire is the prevalence of urban violence across many parts of the world - such violence can be attributed to social factors (motivated by a desire to get or keep social control), economic (motivated by material gain), and/or political ones (motivated by the desire to hold political power) [4]. A comparative line has also been established across cities such as Sao Paulo, Buenos Aires, Los Angeles, and Mexico City characterized by discourses of fear and practices of extreme class segregation [5]. There is also the examination of "wounded cities" ruptured by sudden, unpredictable events or by more chronic problems that undermine quality of life [6].

I have studied "polarized" or "contested" cities where the very legitimacy of their political structures and their rules of decision-making and governance are strongly contested by ethnic groups who either seek an equal or proportionate share of power or demand group-based autonomy or independence. Governance amidst severe and contested multicultural differences is viewed by at least one identifiable group in the city as artificial, imposed, or illegitimate. Socioeconomic cleavages and urban questions become bound up with strong political claims; socially "divided" cities at this juncture become politically "polarized" cities. The case cities I have investigated are a sample of a troubling number of cities across the world that are prone to intense inter-communal conflict and violence reflecting ethnic or nationalist fractures. In these cities and societies, ethnic identity and nationalism combine to create pressures for group rights, autonomy or even territorial separation. Political control of multinational cities becomes contested as nationalists push to create a political system that expresses and protects their distinctive group characteristics. From an analytical perspective, polarized cities are illuminators of basic tensions found in many cities, but in polarized cities these tensions commonly take on overt political aspirations and often quite obvious physical and socioeconomic effects. Because of this "revealed" quality, polarized cities are far from being extraneous to urban conflict studies and actually are central to our understanding of the less volatile, although no less real, group and political dynamics found in non-polarized, multicultural cities.

Cities such as Jerusalem, Belfast, Johannesburg, Nicosia, Montreal, Algiers, Sarajevo, Mumbai (Bombay), Beirut, Brussels, and now Baghdad have experienced inter-group conflict and violence associated with ethnic or political differences. In cases such as Jerusalem and Belfast, a city is a focal point or magnet for unresolved nationalistic ethnic conflict. In other cases (such as certain Indian or British cities), a city is not the primary cause of inter-group conflict, but becomes a platform for the expression of conflicting sovereignty claims involving areas outside the urban region or for tensions related to foreign immigration. The November 2008 violence targeting Mumbai is a recent manifestation. In cases such as Johannesburg and Beirut, the management of cities holds the key to sustainable co-existence of antagonistic ethnic groups subsequent to cessation of overt hostilities. In other contested cities such as Brussels and Montreal, there have been effective efforts to defuse nationalistic conflict through power-sharing governance and accommodation to group cultural and linguistic differences.

\section{METHODS FOR STUDYING CONTESTED CITIES}

The value of research on politically contested cities will increase if investigators use a comparative approach that utilizes the richness of the single case study approach but goes beyond a single case study to make comparative assessments across multiple contested cities. This dual focused comparative approach [7] has the following characteristics:

- $\quad$ resembles the intensive case study approach in that it examines each case in depth.

- examines multiple cases and makes comparisons among them.

- $\quad$ proceeds by asking a limited number of questions, or testing a limited number of hypotheses, so that comparability across cases is enhanced.

- allows for additional and unique queries to be addressed in a case in order to bring out unique features of a case, thus allowing for built-in flexibility.

Schnabel [8] describes this comparative case study approach as able to produce two types of knowledge - that of a general nature derived from the comparative study of the dynamics of conflict societies, and knowledge of a more specific nature, linked to the specific nature of each conflict city under investigation. Comparative evaluations across cities seek to generalize findings by going beyond single case studies that, although rich and penetrating in analysis, often have limited value in terms of the extrapolation of general lessons useful to local and external actors alike. For polarized cities, the contentious assumption embedded within the comparative approach is that the societal divisions, interethnic dynamics, and possible policy responses have some generalizable nature to them and that these general patterns can be identified and contrasted with the endemic and unique attributes of the cases ${ }^{1}$. This analytic approach assumes a middle ground between universalist and culturalist approaches to comparative research, and treats the context itself as a key explanatory variable in making comparative assessments [9]. Through the deliberate selection of cases that show certain similarities and the inclusion of cases that illustrate significant variation on key criteria, we can isolate key enabling and blocking factors that influence the dynamics of interest [10].

In my specific examination of urban policy and planning in polarized cities, a comparative case study approach seeks to add to the body of knowledge about the differing contexts within which urban policy and planning practice operates

\footnotetext{
${ }^{1}$ I have presented numerous comparative assessments of polarized cities to audiences across the world, including in specific contested cities. A common critique of my work, and a resistance on the part of these local audience members, is their perception that their circumstances are radically different and unique from others and that by drawing out similarities across cases I am reducing their complexities to simplified and inaccurate portrayals.
} 
cross-nationally $[11,12]$. It seeks to escape the assumptions and values of much single-country urban planning studies, bound to a particular context and stage in the development of planning thought [13]. I have aimed to document the attributes and effects of policy strategies that may transcend particular urban and ideological contexts, while acknowledging the unique national and local contexts of specific cases. One of my working assumptions has been that there are aspects of city planning and policy processes that can be inherently harmful or beneficial to urban intergroup relations in ethnically polarized environments, and that such patterns and effects hold across conflict settings of otherwise diverse natures.

A project studying the complex and multi-faceted topic of societal and urban conflict benefits significantly from an interdisciplinary approach. I have utilized the insights of political science to examine the political and legal arrangements and mechanisms used to diffuse or moderate conflict. I have used knowledge of urban and regional planning to study policies affecting local and metropolitan settlement patterns, the perspective provided by geography to explore the spatial and territorial aspects of conflict and its management, and the social psychology literature to analyze group identity and how urban attributes may facilitate or obstruct aggression.

Essential to comparative research work is the use and development of crosscutting, integrative themes able to illuminate similarities (and differences) across cases. In multiinvestigator, multi-site research, these crosscutting and integrative themes or prior theoretical assumptions provide basic parameters that can anchor and shape the efforts of numerous investigators in different locations. As much as possible, concepts should be used consistently across case study locations. This will increase the credibility and dependability of qualitative findings, and the internal validity and reliability of quantitative results [14]. A cross-case thematic structure that provides programmatic guidance will likely be more necessary for multi-investigator studies than it will be for single-investigator investigations. In the latter case, the sole researcher has more maneuverability to develop connective themes incrementally and organically from the evolving field research while still maintaining research program coherency.

Smyth and Darby [15] cite a recent shift in scholarship towards comparative analysis of ethnic conflicts and approaches to conflict resolution, and predict that this trend will continue and deepen because the need for practical, policy-based guidance is intensifying. There exist several comparative assessments that use primarily qualitative or mixed methodologies [16-24]. Non-qualitative studies of conflict and post-conflict societies, meanwhile, address the topic through large-case quantitative analysis and the use of measurable indicators available across diverse settings [25-27]. Typically, comparative studies of ethnic conflict emphasize national and political elements of contested societies more than on-the-ground urban policymaking and governance features.

\section{Field Research and Interviews}

A researcher studying conflicted cities should utilize both qualitative and quantitative research in order to obtain as complete a picture as possible of this multi-dimensional topic. Qualitative methods such as ethnographic observation and open-ended interviewing are particularly useful when the structures of meaning or action are complex or little understood or when the subjective experiences of actors are important to understand [28]. In my research, these aspects have included the motivations and perspectives of local professionals, community advocates, and political officials and the social-psychological states of city residents. My main primary research tool has been the face-to-face interview, which I used to both obtain objective information and to construct a grounded, ethnographic account of urban management amidst societal reconstruction and political strife. I have interviewed, primarily during 1994-1995 and 20032004, approximately 220 political leaders, planners, architects, community representatives, and academics (Table 1). I have been interested in the complex objective realities and influences in these cities, as well as how interviewees make sense of their everyday activities, professional roles, and organizational environment. I have sought to understand the organizational, cultural, and historical context within which governmental and nongovernmental professionals operate. I used interviews to construct an ethnographic account of urban policymaking amidst political strife, based on close observation of the agents' own knowledge and understanding of their actions. I observed closely the interplay between the professional norms and values of many planning roles and the more emotion-filled ideological imperatives that impinge daily upon the professional's life. The distortions, the omissions, the emphases on some issues and not others, and how urban issues and constituents are defined, are all part of the story I wanted to tell of urban policymaking amidst contested ethnicities.

Table 1. Interviews Conducted

\begin{tabular}{|lc|}
\hline Phase I: 1994-95 & \\
Jerusalem & 40 \\
Belfast & 34 \\
Johannesburg & 37 \\
Phase II: 2003-04 & \\
Barcelona & 55 \\
Basque Country & 15 \\
Sarajevo & 17 \\
Mostar & 22 \\
(Note: Nicosia research did not involve formal interviews) \\
\hline
\end{tabular}

Because ethnic affiliation and government employment may influence interviewees' judgments, strong efforts were made to interview individuals so that there would be a fair distribution across ethnic groups, and across government and nongovernmental officials. The classification of interviewees in the Jerusalem and Belfast cases by nationality and affiliation is presented in Table 2. When engaged in research on public policy in contested urban settings, it is important that the pool of interviewees in each of the cities represent adequately and broadly the complexities, arguments, and emotions of working and living in a politically contested city. At the same time, in order to increase the policy relevance of research, interviewee samples may need to be biased toward individuals in the "practical middle" - those individuals with moderate, centrist views on urban ethnic conflict and its 
management. This will increase our ability to identify possibilities in which urban policy can contribute constructively to urban and regional peace and thus increase the practical relevance of our research. Nonetheless, more extreme attitudes toward conflict management should also be included within each of the interview samples in order to understand constraints facing proposed policy changes ${ }^{2}$.

Table 2. Classification of Interviewees

\begin{tabular}{|lr|}
\hline JERUSALEM & \\
Nationality & 24 \\
\hline Israeli & 15 \\
Palestinian & 1 \\
Other & \\
& 12 \\
Affiliation & 11 \\
Governmental (Israel) $^{\mathrm{a}}$ & 17 \\
Academic $^{\text {Nongovernmental organization }}{ }^{\mathrm{b}}$ & \\
\hline BELFAST & 16 \\
Ethnicity & 12 \\
Protestant & 6 \\
Catholic $^{\text {Not reported }}$ & \\
& \\
Affiliation & 19 \\
Governmental & 7 \\
Academic & 8 \\
Nongovernmental organization & \\
\hline
\end{tabular}

${ }^{a}$ Includes both current and former government officials.

${ }^{b}$ Includes those who worked for the then-emerging Palestinian National Authority

The study of the multidimensional political, territorial, historic, economic, and social-psychological attributes of contested urban societies requires a deeply grounded, intensive case study approach utilizing immersion in a city's dayto-day culture. The depth of inter-ethnic realities, and the time-consuming nature of interview scheduling and questioning, demands that the scholar/investigator spend multiple months of research in country. In addition to allowing for face-to-face interviewing, in-country residence allows the investigator to become immersed in the intriguing and contentious day-to-day conditions and concerns of "polarized" urban life, as expressed by public officials and people on the street, and through popular media. Collaboration with local academic institutions will support and deepen the research experience. These local institutions can provide invaluable research hospitality, an important set of initial community contacts, and an academic base of office support that can ease interview scheduling and other logistical arrangements.

I developed core interview lists, based on my primary field contacts, prior to the in-field research portion of the project. Additional interviewees were identified after arrival based upon word-of-mouth referrals from initial discussants and through local media. Interviews lasted 75 minutes, on average, and about 90 percent of them were audio-taped. In

\footnotetext{
${ }^{2}$ In addition to interviews, secondary sources can be used to help construct the more hard-line positions of right-wing interests and rejectionists.
}

about 10 percent of the cases, I used a translator to facilitate discussion. Interviews were transcribed and input into a qualitative software program that helped me to document themes and portrayals that connected across multiple interviewees, and also to note multiple, contrary interpretations or ones specific to particular types of interviewees. I used noninterview data sources to "reality-check" interviewees' assertions. I investigated published and unpublished government plans and policy documents, political party platforms and initiatives, implementing regulations, and laws and enabling statutes in terms of how they address inter-group difference. I also employed quantitative data concerning growth and housing trends and budgetary spending ${ }^{3}$.

\section{Guiding Research Issues}

A set of issues should be constructed to frame and shape comparative qualitative research on contested cities; this provides the structure and parameters for interview and secondary source research. The issues I focused on, listed in Table 3, examined the influence of ethnic polarization on the city's institutional context, formulation of development goals, public agenda setting, decision-making, and policy implementation. I concurrently evaluated how city policies that are enacted affect the nature and level of ethnic conflict. Throughout, the focus was on how ethnicity permeates the goals and processes of urban management, and how urban decisions in turn constrain or open opportunities for conflict alleviation.

Table 3. Guiding Research Issues for Case Studies - Main Categories
Contextual Factors
Policy Issues and Goals
Urban Decision Making
Policy Outcomes
Conflict Outcomes and Mechanisms
Community Dynamics and Organization
Change and Evolution

I investigated contextual factors that institutionally and legally structure the decision-making environment. Legal frameworks and city and neighborhood organizational arrangements may condone institutional differentiation or seek to integrate or unify ethnic groups within a common public domain. I examined policy issues and goals in each ethnically polarized city, focusing on the position that urban policymakers and administrators take via-a-vis ethnicity whether they accept it as a decisionmaking criterion or not. Policy goals are important to study because they articulate a state's (and city's) governing ideology. Such an ideology, as used here, is a comprehensive political belief system that embraces an inner logic and seeks to guide and justify organized political and social actions [29]. A state's urban gov-

\footnotetext{
${ }^{3}$ The use of secondary data was instrumental in analyzing citywide and neighborhood trends impacting upon the groups in conflict. Information on service delivery and quality, housing availability, and magnitude of development are usually accessible through public bureaucracies or nongovernmental organizations and can be categorized by city neighborhood to provide an understanding of whether urbanism is increasing inter-group disparities and thus potentially ethnic tension.
} 
erning ideology can tend toward "ethnonationalist" and promoting of an exclusive nationalism or "civic" and promoting of a universalist ethic and inclusive nationalism.

The next domain of questions, urban decision making, is composed of both public agenda setting and the selection of preferred policies. The local policy and planning alternatives that are considered can be restricted by ethnonational and political realities and the rationales underlying public decisions can expose clearly a government's role within, and position toward, ethnic polarization. In my research, it has been instructive to think of four options or models that public policymakers and administrators can use when addressing issues of ethnic salience in contested/polarized cities (Table 4). A neutral urban strategy employs technical criteria in allocating urban resources and services, and distances itself from issues of ethnic identity, power inequalities, and political exclusion. A partisan urban strategy, in contrast, chooses sides and is a regressive agent of change. The equity strategy gives primacy to ethnic affiliation in order to decrease, not perpetuate, inter-group inequalities. The final model-a resolver strategy-seeks to connect urban issues to the root political causes of urban polarization-power imbalances, subordination, and disempowerment.

Table 4. Models of Urban Policy Strategies (Adapted from [30])

\begin{tabular}{|c|l|}
\hline Strategy & \multicolumn{1}{|c|}{ Tactics } \\
\hline \hline Neutral & Address urban symptoms of ethnic conflict at individual level. \\
\hline Partisan & Maintain/increase disparities \\
\hline Equity & Address urban symptoms of ethnic conflict at ethnic group level. \\
\hline Resolver & Address root causes/sovereignty issues. \\
\hline
\end{tabular}

The next set of research questions explores policy outcomes-the implementation of policy by administrative agents-and constitutes an important lens through which to evaluate the relationship between governing ideology and its urban operationalization. I closely examine on-the-ground outcomes in terms of the distribution across ethnic communities of land use planning restrictions, building permit allowances, housing development, economic activities, transportation, and urban services.

Questions focused on conflict outcomes and mechanisms do not evaluate direct on-the-ground outcomes of urban policy decisions, but how particular policies affect the nature and level of ethnic conflict and tension. Objective outcomes of policy can be significantly different than political-psychological ones in polarized cities because any extension of public authority-even one premised on a criterion of urban fairness-may be deemed as illegitimate and stimulative of resistance and conflict. Mechanisms for coping with ethnic conflict during policy implementation may utilize governmental channels of inter-ethnic mediation or informal contacts between government and minority elites. The next set of issues relates to community dynamics and organization and explores survival techniques used by a subordinated population ("out-group") and the processes of inter- and intra-group community mobilization. Questions focus on how ethnic community groups can shift from being solely organs of protest and resistance to constructive co-participants in the creation of alternative urban scenarios.

The final set of inquiries probes potential change and evolution in how local governing regimes address ethnic polarization. Planning goals and strategies may shift over time due to changes in economic, political, or ideological factors. Change may be either progressive, moving the urban system closer to political accommodation, or regressive, tightening further the opportunities for co-existent viability of antagonistic urban communities. I am interested in how urbanists respond to policy crisis and contradictions and the arguments they use to buttress their efforts. Acting amidst such urban contentiousness, urban policymakers and planners may adopt a narrow vision of their roles or a position more conducive to change that facilitates problem re-framing and social learning.

\section{Use of an Analytic Lens}

It is useful when engaged in comparative urban research in contested societies to employ a specific lens through which to study wider issues of urban governance and policymaking. The focus on a specific disciplinary perspective helps to anchor research questions and guides the selection of prospective interviewees. Without such anchoring, the study of such a multidimensional and interconnected phenomenon as the urban system can become unwieldy and prone to analytical obtuseness. An investigator should be explicit about the lens or frame of reference being used so that readers can ascertain what is inside and outside the boundaries of research and judge the appropriateness of using this frame as a way to study larger phenomena [31].

I have employed a focused lens as one would use a key to open a door; once the door is open, the richness and complexity of the urban governance domain is revealed. Based on my mentorship and discussion with students about their own research in international settings, and based on my own experience, I am aware of the difficulties of getting a handle on complex and interdisciplinary subject matter without the use of a focal device. It is important to note that such an analytic lens focuses the researcher's initial approach to the subject matter but does not necessarily constrict the coverage of the research project over time. Thus, the researcher confronts the subject matter loaded with the specific knowledge of his/her disciplinary focus in order to open doors, but also should be armed with understandings of the case from multiple and diverse theoretical and practical viewpoints. This assures that once the researcher is "in the door" that he/she will be capable of developing interpretations that connect these multiple perspectives. Within the focused disciplinary area that I use, my expectations about what I expect in case study research take on the form of traditional hypotheses. In other disciplinary and theoretical areas that are outside my primary area of expertise, my approach resembles more that of "grounded theory", where I use the specifics of my findings to develop "upward" those propositions and models that can account for observed patterns of government behavior and individual perceptions.

The main analytical lens in my research has been urban planning policy. Planning and urbanism are at the root of my academic training and disciplinary expertise. In addition, I find that the planning function of government, through its 
direct and tangible effects on ethnic geography, can clearly reveal the intent and role of a governing regime. As stated by Wright and Rabinow [32], "both architecture and urban planning, both designs and ordinary buildings, offer privileged instances for understanding how power operates." Urban planning is only one form of intervention into the cityscape and some readers may view it at first as unnecessarily narrow in scope and mundane in exercise. I am also open to criticism that other urban activities - such as public education and urban policing - are salient to issues of group conflict and should be studied. Nevertheless, in order to maintain a coherent analytical focus, I focus on planning-related and often land-based policies that structure opportunities and costs in contested cities, rather than on the maintenance of societal order through police and military force.

I use the terms "urban planner" and "urbanist" in a way that broadly encompasses all individuals (within and outside government) involved in the anticipation of a city's or urban community's future and preparation for it. My use of these terms is far more expansive than that defined by the city (town) and regional planning profession, specifically. The terms include, within government, town and regional planners, urban administrators and policymakers, and national and regional-level urban policy officials. Outside government, it includes community leaders, project directors and staff within nongovernmental, community or voluntary sector organizations, scholars in urban and ethnic studies, and business leaders.

The focus of my research has been on urban policies that have direct and tangible impacts on cultural and built local environments. These include land use planning, real estate development, economic development, reconstruction, housing construction and allocation, refugee relocation, capital facility planning, social service delivery, community planning and participation, and municipal government organization. I have studied how urban policies affect the spatial, economic, social, and political dimensions of urban space, and whether, and how, policy interventions can intensify or lessen intergroup hostility. Urban planning policies affect at least four specific types of conditions - territoriality, economic distribution, policymaking access, and group identity - that can exacerbate or moderate inter-group tension [33-37] (Table 5).

Urban policy most concretely affects the ethnic conditions of the urban environment through its significant influence on control of land and territoriality [33, 36, 38]. Territoriality is "the attempt by an individual or group to affect, influence, or control people, phenomena, and relationships, by delimiting and asserting control over a geographic area" [37]. In other words, an urban regime or an ethnic group living in the city will seek control over urban space as a way to secure political control. These policies create urban frameworks that foment ethnic mistrust and conflict [38]. Two common techniques of territorial control amidst ethnic tension aim to alter the spatial distribution of ethnic groups and to manipulate jurisdictional boundaries to politically incorporate or exclude particular ethnic residents [39]. Control over human settlement patterns can be exercised primarily through two functions of government-regulatory and developmental. These governmental interventions can significantly affect in a polarized city the demographic ratios be- tween the two sides, change the scale of focus of planning efforts, and reinforce or modify the ethnic identity of specific geographic subareas.

Urban policy substantially shapes the distribution of economic benefits and costs and the allocation of urban service benefits $[33,34,38]$. Urban land use and growth policies affect such aspects as the accessibility and proximity of residents and communities to employment, retail and recreation; the distribution of land values; and the economic spin-offs (both positive and negative) of development. The planning and locating of economic activities can significantly shape both the daily urban behavior patterns and residential distributions of ethnic groups. The development of economic centers of activity can either integrate or separate the ethnic landscape. For example, major employment or commercial centers could be placed along ethnic territorial interfaces as a way to turn formerly "no-man's land" into mutually beneficial spaces of inter-group economic and social interactions. In contrast, economic development that occurs amidst a single group's territory can to solidify or reinforce inter-group separation. Urban service and capital investment decisions - related to housing, roads, schools, and other community facilities - may be used to consolidate intergroup inequalities across a polarized city's ethnic geography by distributing benefits and advantages disproportionately to the ethnic "in-group". Alternatively, urban spending can be directed disproportionately in favor of a disadvantaged group in an effort to remedy past inequalities.

Table 5. Urban Ethnic Conditions Affected by Policy

\section{Territoriality/Control Over Land}

Settlement of vacant lands; control of settlement patterns; dispossession from land; return and relocation of displaced and refugee populations; control of land and ownership; demarcation of planning and jurisdictional boundaries vis-à-vis ethnic settlement patterns.

\section{Distribution of Economic Benefits and Costs}

Magnitude and geographic distribution of urban services and spending; allocation of negative and positive "externalities" of urbanization.

\section{Access to Policy-Making}

Inclusion or exclusion from political process; formal and informal participation processes; presence and influence of nongovernmental organizations.

\section{Group Identity}

Maintenance or threat to collective ethnic rights and identity; education, language, religious expression, cultural institutions.

Urban policy and planning processes can have substantial effects on the distribution of local political power and access to policy-making [38]. Models of conflict regulation commonly applied at national levels (summarized by O'Leary and McGarry [40]) help illuminate different participatory and political options at the city government level. These models include hegemonic control, third-party intervention, cantonization (devolution), and consociationalism (elite power-sharing). Aspects of conflict-accommodative government-such as power sharing, ethnic proportionality within public sector, community autonomy, and minority vetoes have been applied in some bicultural urban settings (such as Brussels). In many contested cities, there may be a legacy of hegemonic control by one ethnic group where the opposing group has been fully excluded from the political decision- 
making process. Of particular relevance to the urban level is the use of local power-sharing arrangements as part of transitions from a local authoritarian or "ethnic" state to some form of democracy, and the use of ethnic proportionality standards in decreasing historic biases in political representation and public employment. In circumstances where access to policy-making is substantially curtailed for one urban ethnic group, pressure for change often is redirected through nongovernmental channels. The web of nongovernmental and voluntary associations that deal with urban issues related to community development can be an important source of glue holding together a threatened or disempowered minority, providing access to international organizations and their funding, and advocating for change through documentation, demonstrations and protests [41-43].

The final type of condition potentially affected by urban policy, group identity, is critical to the nature of inter-ethnic relations in a polarized city. Collective ethnic rights such as education, language, press, cultural expression, and religious beliefs and customs are connected to potent ideological content. Exercise of these rights is often viewed by a subordinated "out-group" as a critical barometer of an urban government's treatment of their collective identity. In a polarized city, group identity is commonly reinforced through ethnonationalist expressions in the urban landscape, such as symbolic buildings linked to opposition political expression, administrative centers of pseudo-state activity, and murals and other graphic expressions of resistance and territoriality. For an urban sub-group that feels threatened, psychological needs pertaining to group viability and cultural identity can be as important as territorial and material needs. Urban policy decisions dealing with the location of proposed new religious, educational, and cultural institutions, or the closing down of ones deemed obsolete, can indicate to urban residents the government's projected ethnic trajectories of specific neighborhoods and can substantially threaten ethnic group identity. In order to attenuate group conflict and advance the prospects for mutual co-existence, a city must be able to affect not only the material conditions, but also the psychological and identity-related conditions, of its different ethnic groups [44].

These urban ethnic conditions- land control, economic distribution, policymaking access, and group identity-are important influences on the degree of urban stability or conflict (Table 6). Movement toward tolerance in a city can be indicated by increased flexibility or transcendence of ethnic geography, lessening of actual and perceived inequalities across ethnic groups, greater inter-ethnic political inclusion and inter-group cooperation, and growing tolerance and respect for collective ethnic rights ${ }^{4}$. In contrast, signs of urban peace impedance include ethnic territorial hardening, solidification of urban material inequalities, an ethnic group's nonparticipation in political structures and cooperative ventures, a public sector disrespect of a cultural group's identity,

\footnotetext{
${ }^{4}$ An argument can be made that a sign of conflict abeyance would be a decline in the demand for collective rights as a city normalizes and the need for group affiliation lessens. However, this lessened salience of group rights would occur over a longer time horizon than studied here. In the years more immediate to urban conflict, I assert that group-based conflict would best be alleviated through the acknowledgement of group rights instead of efforts to bypass or transcend them.
}

and most palpably a continuing sense of tension, intimidation, and potential conflict on city streets and in political chambers.

The full array of urban policies and interventions in a particular contested city, on balance, are capable of both producing a widely shared sense of deprivation conducive to sustained communal resistance and providing a platform for the purposeful and rational actions of inflammatory ethnic group leaders. Because material grievance and political disenchantment can both contribute to urban instability, it is important for urban scholars to detail the effects of government policies on the material and psychological states of urban residents, as well as on an out-group's political organization and expression.

\section{Table 6. Degree of Urban Stability or Conflict}

Facilitation (or Impedance) of Movement Toward Co-Existence

- Decrease (increase) in organized resistance and political violence;

- Loosening (compartmentalization) of ethnic territoriality;

- Lessening (widening) of inter-ethnic disparities;

- Greater (lesser) political inclusion of all groups and inter-group cooperation;

- Growing (eroding) of respect for collective ethnic rights.

\section{City as "Differentiated" and "Partial" Actor}

The effects of urban policies on inter-group relations may not be consistent across functional areas of urbanism. In other words, while the provision of social services by city government may moderate material inequalities between ethnic groups, other policies - such as development control may be hardening territorial entrenchment and thus adding to grievance. Different policy domains may or may not exhibit parallel dynamics of political conflict along inter-communal fault lines. In contested cities, effects of urban interventions may vary across policy domains within city government (horizontal differentiation) and across levels of government (vertical differentiation).

Municipalities involve themselves in a wide range of different policy areas, including housing, development control, education, transportation, economic development, citizen participation, and cultural programs. In some cities, each of these interventions may produce consistent results in improving (or obstructing) group relations. Yet, because each of these functional areas commonly has different administering agencies within municipal government and may have different patterns of policy development vis-à-vis city constituencies, it may be the case that functional interventions may differentially impact aggrieved out-groups - sometimes benefiting them, sometimes hurting them. Differentiation across functional areas of policy intervention by a governmental authority in a contested city sends out contradictory messages to an out-group. In some cases, this may elicit hope by the aggrieved group in an otherwise hegemonic condition. Or, positive advancement in one policy area (in terms of bettering inter-group relations) may lead to a heightening of expectations otherwise not met by other policies. In a more optimistic scenario, facilitation of coexistence by certain policy interventions may provide impor- 
tant lessons to the government authority about how other policies can be re-directed toward similar ends.

Local policy domains also vary in terms of which level of government - state, region, municipality - exercises real authority. Here we examine whether the city government has autonomy to engage in particular urban actions or whether the city is actually implementing policies whose goals and directions are primarily established at higher levels of government. Cases will likely differ in terms of their mixes of jurisdictional engagement in urban policy (some cities will have a great degree of autonomy to engage; others will be more subordinated to the dictates of state and regional authorities), and this mix may impact how policies enacted in the city affect inter-group relations and political conflict. On the one hand, intergovernmental intrusion into the local policy arena by higher levels of authority may decrease the opportunity for city government to be a place of innovative and pragmatic compromise that is needed to confront the ethnic complexity of these cities. On the other hand, more constructive policies by a higher level of government may be able to bypass obstructive local ethnic dynamics that can capture and paralyze local policymaking. In pursuing urbanbased policies that can build peace and stability, it may not be a matter of sorting out the "correct" level of jurisdictional engagement for different policies, but creating arrangements that actualize and stimulate intergovernmental cooperation capable of addressing and transcending often sclerotic nationalistic politics.

Being sensitive to the variability in the degree of horizontal integration (across policy domains within city government) and vertical integration (across levels of government) helps us overcome the simplifying assumptions that treat the "city" as a unitary actor. This perspective increases our understanding of the city instead as a system of sometimes internally contradictory policy domains and at other times as a partial actor hemmed in by higher levels of government. This bears semblance to LeGales' [45] description of cities as "incomplete societies" that are not self-contained collective actors but rather dynamic systems of internal differentiation and external linkages. For policymakers faced with intergroup tension and peace-building challenges, a perspective of the city as "differentiated" and "partial" increases appreciation that there exist multiple access points available for leveraging policy to advance peace, but it also warns policymakers that city government efforts to advance inter-group tolerance in one domain can be countered and undercut by city policies in other domains and/or by actions of other levels of government.

\section{Constructing a Comparative Analytical Framework}

Important in the carrying out of effective comparative urban research is the development of a comparative analytical framework that can provide the scaffolding for making cross-case assessments and evaluations. It has been my experience that this scaffolding is developed over time and emerges organically after engagement in several case studies. Although existing studies by others assisted in the identification of key criteria, the analytical framework I developed came out of making sense of the differences and similarities across diverse case study cities. The framework did not emerge fully fledged and resolute, but was the result of in- crementally stumbling through comparative findings. It has felt consistently more like a work in progress rather than a final resolution. Indeed, one of the significant benefits of using a comparative framework is not only the insights it provides to case study findings, but also the further questions that are provoked as a parsimonious analytical structure is overlayed atop the rich and complex dynamics of politically contested cities.

Amongst the myriad and multiple dimensions along which cities differ, I focus on the placement of urban regions along an "urban conflict-stability" continuum as a way to provide a necessary comparative context (Fig. 1). I place the eight cities that I have investigated along this 4-category scale depending upon whether the city is experiencing active conflict, a suspended condition of static non-violence, movement toward peace, or urban stability/normalcy. Examining cities along such a continuum provides insight into the range of possible interventions by city governing regimes amidst inter-group differences ${ }^{5}$. In placing cities along the continuum, I focus on a sole overriding criterion among multiple urban dimensions - the degree that active inter-group conflict over root political issues has been effectively addressed through inclusive institutional and constitutional means ${ }^{6}$.

This urban conflict-stability continuum is not intended to be a comprehensive measuring tool but rather a useful heuristic model. Positioning case study cities conceptually along such a continuum allows one to induce from the specifics of the cases a set of broader implications for the ability of cities to be local contributors to societal peace building. It enables the researcher to think about the differences across types of contested cites and what these differences mean for urban intervention and national peacemaking. I posit that cities may be classifiable in terms of their vulnerability to political violence and that the potential for such violence is related to the degree that active inter-group conflict over root political issues has been effectively addressed. Other measures of urban life would assuredly comprise an important part of a more comprehensive urban index of stability/ instability. For instance, efforts to assess vulnerability to conflict and instability are included in the Human Development Index [46], probability of urban terror assessment [47, 48], and urban violence risk [21]. There also exist criteria evaluating national level vulnerability that could be incorporated into urban assessments [49-53]. Yet, the parsimonious nature of the single-dimension scale is also a benefit.

\section{Category 1 - Active Conflict}

In these cities, hostility, antagonism, tension, and at times overt violence, exist between urban groups. This is so because the root political issues of the broader nationalistic conflict remain unresolved. In such a circumstance, the city becomes a flashpoint, platform, and/or independent focus of broader conflict. When there is such active urban conflict

\footnotetext{
${ }^{5}$ In terms of formal research design, my approach to the study of contested cities does not use a true "comparative case study" approach where all the selected cases would be similar in societal conditions and only the type of urban intervention would vary.

${ }^{6}$ The use of this continuum in no way implies that there exists a simple linear progression from conflict to post-conflict. Rather, peacemaking and peace building are subject to fits and starts, regressions, and great uncertainty.
} 
Fig. (1). Conflict-stability continuum ${ }^{* * *}$.

${ }^{* * *}$ Defined by the degree that active inter-group conflict over root political issues has been effectively addressed through inclusive institutional and constitutional means.

and a vulnerability of the urban arena to deeper nationalistic currents, urban policy and planning approaches will likely become rigid, defensive and partisan in efforts to protect the governing group in this unstable environment.

\section{Category 2 - Suspension of Violence}

In these cities, there is tenuous cessation or suspension of urban strife but not much more. A city is marked more by the absence of war than the presence of peace. After the ending of overt conflict, there will likely remain deep segregation or partitioning of ethnic groups in the city, local politics may persist in parallel worlds, and there may still be tension on the streets. This is because the legacies of overt conflict live on far past the duration of open hostilities themselves. In category 2 cities, however, this potential for inter-group differences to inflame violent actions is lessened due to a negotiated agreement between nationalist elites, intervention by a third-party mediator, or even the construction of a wall that physically separates conflicting nationalistic camps. Although this is a significant advance, suspension of overt conflict is only a starting point in urban peace-building and requires important steps in the future that bring positive changes to a city in the forms of tolerance, openness, accommodation, and democratic and open participation. Without these movements toward peace on the ground, a city will stagnate and be vulnerable to regressive violent and political acts.

\section{Category 3 - Movement Toward Peace}

In these cities, there are efforts to transform urban conflict geographies to peace-promoting ones and to use urban and economic development policies to transcend ethnic and nationalist differences. Decisions regarding the built environment, provision of economic opportunities, and delivery of public services are done in ways that create and promote urban spaces (both physical and psychological) of intergroup co-existence. Examples may include providing flexibility in the urban landscape to facilitate mixing of different groups if and when they desire it, creation of cross-ethnic joint planning processes, establishment of economic enterprises in areas that link different ethnic communities, provision of public spaces that bridge ethnic territories, sensitive oversight of the location of proposed development projects explicitly linked with one ethnic or religious group (churches, mosques, community centers), post-war reconstruction and relocation decisions that do not solidify wartime geographies, and provision of community services in ways that bring youths together so they can learn from each other. Although category 3 cities show movement toward normalcy, local peace-building efforts remain experimental in the sense that full urban stability has not yet been reached. Remembrances of trauma and conflict remain below the sur- face, and they can be stimulated by local public policies that are not sufficiently sensitive to these scars.

\section{Category 4 - Stability/Normalcy}

These cities represent a fundamental turning point where there is the consolidation of peace-building, a beginning in the transcendence of inter-group differences, and the undertaking of fundamentally new directions in urban governance and policymaking. An important threshold is passed when nationalistic and inter-group differences take place solely within political and legislative channels with no or little threat of a resort to political violence. Regarding urban development specifically, category 4 cities are more able than category 3 cities to enact policies that fundamentally redistribute the costs and benefits of city growth, reverse growth ideologies that guided the former governing regime, and imprint on the urban landscape values such as public access, equality, and democratic participation.

In terms of theoretical and conceptual development regarding the study of politically contested cities, misfits or paradoxes when locating cities along a comparative analytical measure can shape and stimulate further inquiries into the nature and dynamics of urban and national peacemaking. In this way, a comparative scaffolding not only attempts to make sense of case study findings, but also provides footing for further theoretical advances and case selection choices as a research program progresses ${ }^{7}$. The choice of further case cities as a research program progresses is a critical shaper of future work and an important influence on the potential robustness of comparative findings [54].

\section{RESULTS}

\section{Vignettes from 8 Polarized Cities}

I now present selected research findings that exemplify the types of observations available to an investigator using an urban planning and policy lens, and highlight how theo-

\footnotetext{
${ }^{7}$ For example, this scaffolding pinpointed the types of cities instructive for me to study in the second main round of field research in 2003-2004. The inclusion of Spanish city cases in my second phase research program came about because Spain's reputed transitional success in moving from authoritarianism to a functioning democracy attracted my attention as a likely "positive" example that would contrast with, and inform, the cases of more difficult transitions investigated in my earlier work. I also expected to find in my second phase, beyond a simple contrast between Spanish and Bosnian cases, intra-state variation (that is, within each country, one city will be more advanced along the continuum than the other). To the extent this would be true, it would provide an opportunity to study those attributes, independent of national context, which have caused certain cities to be further ahead as peace builders while other cities lag in this capacity. The Basque Country "exception" (i.e., its long struggle with political violence) within an otherwise successful national case was ripe for study because it built comparative elements into the research design.
} 
retical and conceptual understandings can make sense of case study findings. Linking specific knowledge of case study cities with broader conceptualizations is essential in cross-national research. In the following sections, bold and italicized words connect to earlier theoretical material.

\section{Jerusalem (Year of Field Research-1994)}

Israel has used a partisan model of urban policy strategy, in particular asserting extensive territorial control tactics in ways to substantially restructure urban ethnic conditions to its seeming advantage. The Israeli government, pursuing goals of unification and security, has utilized land use planning as a territorial tool to extend the reach of its disputed public authority. Since 1967, Israeli urban policymakers and planners have pursued the goals of Israeli control and security through policies that entrench a Jewish majority within the Israeli-defined City. These policies have: (1) facilitated the pace and increased the magnitude of Jewish development to assert Jewish demographic strength; (2) influenced the location of new Jewish development in annexed areas to create an obstacle to "re-division" of the city; (3) restricted Arab growth and development to weaken their claims to reunified Jerusalem.

Large Jewish communities in strategic locations have been built throughout the annexed municipal area in order to establish a "critical mass" of Jews in the urban region after 1967 (Interviews: Yehonathan Golani, December 27, 1994 ${ }^{8}$; and Benjamin Hyman, November 9, 1994 ${ }^{9}$ ). Of the approximately 70 square kilometers annexed after the 1967 War, approximately 24 square kilometers (or about 33 percent) have been expropriated by the Israeli government. The "public purpose" behind such expropriations is the development of Jewish neighborhoods. These neighborhoods today in "east" Jerusalem are homes to approximately 160,000 Jewish residents. Since 1967, 88 percent of all housing units built in east Jerusalem have been built for the Jewish population [55]. Israeli planners have restricted, through planning regulations, the growth of Palestinian communities within "Jerusalem." Restrictions take multiple forms: (1) land expropriation; (2) zoning regulations that constrain Palestinian rights to development; (3) use of road-building to restrict and fragment Palestinian communities; (4) "hidden guidelines" of Israeli plans which restrict building volume in Palestinian areas; and (5) the intentional absence of plans for Arab areas that obstructs infrastructure provision and community development. As a result, only 11 percent of annexed east Jerusalem, at most, is vacant land where the Israeli government today allows Palestinian development (Interview: Khalil Tufakji, November 18, $1994^{10}$ ) [56]. The building of the Israeli separation barrier since June 2002, including what will be a 40-mile wall extending alongside and beyond the city's politically contested municipal boundaries, is the most recent and imposing manifestation of Israel's use of planning as political tactic.

The over thirty years of Israeli partisan planning in Jerusalem has produced a socially and psychologically divided city of deep compartmentalization / demarcation of ethno-religious

\footnotetext{
${ }^{8}$ Director, Planning Administration, Ministry of the Interior, Israel.

${ }^{9}$ Director, Department of Local Planning, Ministry of the Interior, Israel.

${ }^{10}$ Geographer, Arab Studies Society and Member, Palestinian-Israeli Security Committee.
}

space and one where there is a widening of material disparities between Jews and Arabs. The collective group identity of Jerusalem's Arabs has been fragmented through Israeli territorial practices and this population feels under constant threat in the city. Strife and conflict remain a fact of life in both the city proper and in the interface areas bordering Israel proper and the West Bank, representing a circumstance of active conflict because root issues of sovereignty and control remain unresolved. Israel's partisan planning interventions appear, paradoxically, to be producing spatial and social-psychological conditions of urban and regional instability antithetical to Israel's goal of undisputed political control. Partisan planning, over the years, has proven an obstacle in reaching a negotiated settlement with the Palestinians that can secure Israel's long-term interests of stability. At the same time, the effects of Israeli urban policies in Jerusalem exhibit some complexity and differentiation in policy effects. For example, social service benefits and economic opportunities in the city have had a tendency to moderate group tension in contrast to land use regulation, development, and transportation decisions in and near Arab east Jerusalem, which have constrained Arab life and exacerbated conflict. In addition, Arab exposure to Israeli democracy provides a potential moderating force, yet Israeli democratic authority in the city exhibits hard-edged qualities and is one Arabs do not accept as legitimate. The moderating effects of policies within the city also have differential geographic impacts across Arab (Palestinian) space, leading to a local population less radical in its antagonism to Israel than is the Palestinian population in the West Bank at large [57].

\section{Belfast (1995)}

In its fragile movement toward peace, Belfast illuminates the difficult challenges of urban peace building as part of a fragile movement toward national peacemaking. Amidst the on-again, off-again national progress toward Northern Ireland peace, policymakers and planners are making tentative and cautious efforts to modify the city's strong sectarian segregation and place-based antagonisms; progress is piecemeal and slow [58]. The 1998 "Good Friday Agreement" specifies a devolved, locally ruled Northern Ireland of shared political inclusion. Day-to-day rule of the province has been transferred from Britain to a new directly-elected Northern Ireland Assembly, in which Protestants (Unionists/Loyalists) and Catholics (Nationalists/ Republicans) have shared power. There has been a marked decrease in political violence to the point of its almost complete absence. Yet, urban policymakers in Belfast must now address how to confront a deeply segregated and territorialized city in ways that can cocontribute to larger peace-making.

For over 25 years, the guiding principles for Belfast urban policymakers and administrators under direct British rule (1972-1999) had been to: (1) position government's role and image in Belfast as a neutral participant not biased toward either "orange" (Protestant loyalism/unionism) or "green" (Catholic nationalism/republicanism); and (2) assure that government policy does not exacerbate sectarian tensions by managing ethnic space in a way that reacts to, and reflects, residents' wishes. In this way, public policy interventions were to maintain and respect group identity. This neutral model of urban policy strategies meant that policymakers, in effect, condoned the strict ethno-political territoriality of the city, one that imposed tight constraints on the 
growing Catholic population while protecting underutilized Protestant land. Urban policymakers in these years had no comprehensive or strategic approach to dealing with sectarian divisions, with the town planning function having largely assigned sectarian issues to policy domains outside its responsibility. For example, the 1987 plan for the Belfast Urban Area stated that, "it is not the purpose of a strategic land use plan to deal with the social, economic, and other aspects involved" [59]. It emphasized instead the 'neutral territory' of the central city and its revitalization. Housing allocation administrators have designed a color-neutral set of criteria that have made them immune to discrimination claims. Yet, this neutrality has been found to reinforce the residential hypersegregation of religions [60]. Agencies involved in constructing new development or housing projects, in contrast, undertook out of necessity tactics of engagement with sectarian neighborhoods that deviated from color-neutral principles and strict maintenance of ethnic territoriality. These policies 'at the sharp edge', however, have been ad-hoc or project-based actions occurring outside a strategic framework aimed at progressive ethnic management.

Despite peacemaking advances at the national level, there has yet to develop a capacitated ethnically shared local governance of Belfast city. However, consistent with Good Friday Agreement principles, local governments are to be reconstituted and empowered. This would be a substantial shift from the direct rule years, when there was vertical differentiation in actual political power. Under direct rule by the British government, most urban policies were decided not by the city council, but by the extra-local Northern Irish government. This voiding of local rule created a circumstance where city council discussions were dominated by sharpened rhetoric and little chance for pragmatic compromises needed to manage urban affairs. A "review of public administration" begun in 2002 calls for existing local councils to be reconstituted before critical public functions such as planning, zoning, and transportation would be devolved to them [61]. Devolution of genuine political power to city government will likely need to introduce a more proactive and progressive ethnic agenda able to move this urban society forward, one that is responsive to the differential and changing needs of both Catholic and Protestant communities. Direct rule utilized an urban policy approach for 25 years primarily aimed at stability, neutrality, and maintenance [62]. This protection of the status-quo defended a rigid and sterile territoriality of significant segregation, and reinforced the physical and psychological correlates of urban civil war. Such an approach will not help Belfast and Northern Ireland advance to a greater level of sectarian co-existence.

\section{Johannesburg (1995)}

Apartheid formally ended in South Africa with the April 1994 national election of a "government of national unity" led by Nelson Mandela. At the local level, city and metropolitan government in Johannesburg was restructured in 1995 to politically link formerly white local authorities with adjacent black townships. From 1991 to 1995, urban leaders engaged in a resolver urban strategy, addressing core political issues of black disenfranchisement while transforming local and metropolitan governance. Officials of the old regime, nongovernmental groups, and representatives of formerly excluded black communities collaborated in a self- transformative process that changed the basic parameters of representation, decision making, participation, and organizational structure. City-building issues dealing with day-to-day consumption concerns and black boycotting of payments for housing rent and urban services were successfully connected by nongovernmental and opposition groups to root issues of political empowerment and local government reorganization. With new political boundaries and the political inclusion of the formerly disempowered black majority, black majorities were subsequently elected in 1995 in all four local governments and the Johannesburg metropolitan council. In postapartheid South Africa, political violence has waned while criminal violence has exploded, spawned by massive racial disparities in material well-being.

In the early years of post-apartheid Johannesburg, city building policies and principles shifted toward an equity urban strategy, aspiring to stitch together apartheid's segregated living areas, integrate the disconnected parts and peoples of Johannesburg, and bring economic opportunities to the marginalized population. On the one hand, policy was directed at alleviating the many short-term, crisis-related needs of the urban fringe poor pertaining to shelter, public health, personal security, and unmet basic needs for water, sanitation, and electricity. On the other hand, policy sought to create a compact and functionally integrated city where the poor are located close to central city employment and other urban opportunities. There was also amidst societal transformation a critical examination of urban policy practice. Two competing paradigms existed-one connected to town planning's historic affinity toward regulatory control; the other rooted in anti-apartheid community mobilization and linked to a more expansive definition of development. The latter paradigm represents an historic attempt to create a system of social guidance that utilizes the legacy and lessons of social mobilization.

A major challenge for policymakers in post-apartheid Johannesburg has been to address severe economic disparities and distressing levels of unmet human needs amidst market-based urban 'normalization' processes - such as employment suburbanization-that threaten to reinforce apartheid's racial geography. For example, as Johannesburg city seeks greater economic opportunities for its black residents, substantial numbers of white residents and white corporate wealth have relocated to the northern suburb of Sandton. Effects of post-apartheid policies have been differentiated by policy type; the provision of voting rights and political empowerment after the fall of apartheid has advanced much more rapidly in places like Johannesburg than economic advancement for the black majority as new democratic governments confront obstructive apartheid-based physical and spatial legacies.

In Johannesburg, the momentous transformation from "white-rule" to majority-rule democracy in the mid-1990s means that the root causes of political conflict have been directly addressed. Thus, on a conflict-stability continuum, this city would be considered one of stability/normalcy. Yet, difficulties surely remain, including rampant crime and gross disparities in urban opportunities across race and income, which make it arguable that Johannesburg is stable. However, I am not alone in this favorable comparative assessment of South Africa; Sisk and Stefes [63] point to its political transformation as holding important lessons for places 
like Northern Ireland and Bosnia. Because Johannesburg is further along the path toward political peace, urban policymakers there have increased opportunities to remedy the gross and inhuman inequalities associated with statesanctioned racial discrimination and state terrorism, and to confront the severe psychological pains and scars that permeate black African society. Indeed, the South African "peace" exposes the vast set of destructive and dehumanizing urban effects of deep political conflict, problems that are not addressed, or are actively suppressed, in places of unresolved political conflict and tensions. The apparent irony on the surface - that non-political criminality is at a severely high level in post-apartheid Johannesburg - illustrates the debilitating after-effects of decades of immoral state policies and shows that inevitable societal dis-equilibrium will linger far after political agreements start a country and city down a road of "peace".

\section{Nicosia (1999)}

The city, and island, is separated by walls, barriers, and a United Nations-maintained buffer zone ("no-man's land) established during the 1974 war. These physical divisions were built upon ethnic demarcation lines first drawn in the early 1960s. This extreme physical partition has created separate and self-contained municipalities on either side of the barrier - Turkish Cypriot to the north, Greek Cypriot to the south. A clear argument against physical partition is its effect on city diversity and functionality. Physical walls, barriers, barbed wire send strong emotive symbols to current and future generations about what policymakers and urban residents accept in resignation. There has been containment of political violence, yet at the same time physical divisions impose a severe compartmentalization of ethno-nationalistic groups. The city of Nicosia represents well the moribund and unsure space of suspension of violence, existing somewhere between active conflict and movement toward peacebuilding. The city and island have been for over thirty years cleanly separated through a physical partitioning into opposing sides. The wall has suspended overt conflict, yet genuine political and social reconciliation dealing with the root causes of the Cyprus problem has remained elusive until the last few years.

Ironically, because each of the two urban regimes has had a territorial base protective of its group identity, this has set the foundation for some bridge-building. There has been some inter-group functional cooperation. For instance, the Greater Nicosia Master Plan 1981-2001 planned for two scenarios (with and without partition), incorporated elements of flexibility and openness, and has facilitated European Unionfunded development of pedestrian areas in the commercial and historic centers on both sides of the line in ways that would enable them to be connected in the future. An important precursor of the Master Plan was the agreement by the two "mayors" of Nicosia to maintain a joint citywide sewer system-also EU funded-encompassing both sides of the divide. Through the years of division, joint technical meetings of Greek Cypriot and Turkish Cypriot town planners, architects and engineers have formed an important bicommunal mechanism, although nationalist opposition sometimes obstructs their meetings in the buffer zone. Physical development policies in Nicosia have had differentiated effects. Whereas the building and maintenance of physical walls tightly constrained citywide opportunities, pragmatic issues dealing with the provision of key public services have nonetheless been discussed and managed collectively. With some lessening of the decades-long political stalemate and openings of Nicosia crossings becoming more regularized as of 2008, this cooperative functional planning done during the long divided years may facilitate the city's normalization under a unified city government.

\section{Barcelona (2003-04)}

Today an urban society of stability and normalcy, Barcelona has been a site of enduring conflict between a regionalist Catalan nationalism and a centralist Spanish nationalism. During the last fragile years of the authoritarian Franco regime and after its demise in 1976, urbanists played a significant role in connecting urban problems with larger political issues for neighborhood movements. Urbanists helped neighborhood organizations analyze their local problems and possible solutions, but they also provided a political orientation with democratic objectives of local democracy and freedom. Whereas the Franco regime wished to separate urban issues from broader ones of political/social conflict, urbanists made the point that urbanism - the way cities grow, the under-provision of public services and opportunity - was very much part of the larger political question facing Spain and Catalonia. In their ability to link the urban to the political, urbanists in Barcelona in the 1970s were engaged in a resolver urban strategy.

Urbanism - both long-range comprehensive planning and smaller-scale project design - played an instrumental role in pursuing a collective public interest and in constructing the urban terrain upon which a multinational democracy has grown (Interview: Juli Esteban, April 19, 2004 ${ }^{11}$ ). The tool of large-scale urban planning was used - both during and after the transition from Franco to democracy - to change the prevailing logic of unregulated speculation in the city and institute a collective project that used an equity-based urban strategy to distribute urban benefits to both ethnic Catalan and Spanish immigrant neighborhoods and households. It showed that there was another way to structure cities, and asserted the "authority of the public interest over the private interest" (Interview: Joan Antoni Solans, January 22, $2004^{12}$ ). Urbanists intervened early in the political transition to democracy (1975-1979) and this increased planning's effectiveness as a shaping and focusing tool in building a more equitable and livable post-Franco city. The General Metropolitan Plan (GMP) of 1976, in particular, was a key planning intervention, providing the opportunity, during unsettled conditions, for the building of consensus among numerous sectors of society that had different prescriptions about how to reform society [64].

After the formal establishment of democracy, focused architecture and design interventions in the early 1980's assumed greater influence than large-scale planning. Smallscale urban projects in the 1980 s showed people what democracy was, targeted historic material inequalities, and

\footnotetext{
${ }^{11}$ Director, Territorial Planning Program, Secretary of Territorial Planning, Department of Territorial Planning and Public Works, Generalitat de Catalonia.

${ }^{12}$ Director of Planning, Generalitat de Catalonia (1980-2001) and co-author, General Metropolitan Plan of Barcelona.
} 
helped develop public acceptance of the new post-Franco urban regime. The interventions educated the public about the potential of democratic and collective action; "the recovery of public spaces in the neighborhoods, the creation of new parks, and the renovation of the central city were very pedagogical in their content" (Interview: Manuel de SoláMorales, July $12,2004^{13}$ ). Progressive architects and political leaders who outlasted the regime understood the importance of connecting design, community life, and political expression and were key actors in early democratic urbanist practice in the 1980s. Urban interventions targeted improvement of public spaces because these communal areas were of primary importance to neighborhoods, facilitated mix and contact among a heretofore contained populous, provided avenues for collective expression, and were thus important in developing a civic nationalism in Barcelona.

Interestingly, mismatches in perspectives (vertical differentiation) between national, provincial, and city governments have provided Barcelona policy entrepreneurs with opportunities that they have exploited for the city's advantage. Barcelona has employed event-driven urbanism (such as the hosting of the 1992 Olympic Games) to stimulate intergovernmental cooperation between national, regional, and local governments that otherwise would be bogged down by state-city conflict over Catalan nationalism and by political disagreements between a progressive city government and what for many years was a more conservative regional Catalonian government. Since the end of the Franco regime in the 1970 s, strong Catalan identity has been strengthened within a system of democratic political inclusiveness. A place-based and inclusionary (rather than ethnic and exclusionary) nationalism has developed that has accommodated both Catalan and Spanish group identities. This inclusive and cosmopolitan nationalism - integrating international linkages and openness with its cultural heritage and history - appears an enviable goal for the many cities in the world that battle with competing nationalisms that are exclusionary of others.

\section{Basque Country Cities (2004)}

Basque planning and urbanism have provided a space of rationality and pragmatic dialogue in a society where political debate has been constrained by militant nationalism and distorted by violence supporting Basque independence from the Spanish state. The Basque Country combines dynamism at the urban level with stasis and disability at the larger political level. In urban affairs, Bilbao, San Sebastian, and Vitoria have city governments that are active, partnering, internationally connected, and financially able to affect change on the ground. Urban programs and policies have spawned cooperation between public agencies that have transcended differences on larger nationalistic issues. For example, the creation of an intergovernmental partnership among public entities, Bilbao Ria 2000, to redevelop the city's obsolete waterfront brought together local actors (region, county, and city) and the central Spanish government that otherwise would not have worked together due to the larger political Basque nationalist tensions [65]. Functional cooperation and inter-group consensus have developed around the concrete goals of economically restructuring and physically

\footnotetext{
13 Architect and Professor, Escola Technica Superior d'Arquitectura de Barcelona (ETSAB), Universitat Polytechnic de Catalonia.
}

resurrecting the aging and obsolescing industrial city of Bilbao. This urban level of workable compromises provides a laboratory in Basque Country for the working through of differences and the creation of interorganizational linkages not constrained by larger political divides.

Urbanism has been instrumental in redefining the terms of public debate and this has led at times to transcendence of entrenched political views. Significant urban redevelopment is helping to project another image for the Basque Country beyond terrorism and industrial decline. The success of the Guggenheim Museum in Bilbao, and numerous other investments both completed and prospective, presents an alternative view of the Basque Country to the world, one that is cosmopolitan, open, and future-oriented rather than one closed in ideologically and economically. The impetus behind many urban projects in the region has been to create a different appearance for both external audiences (Spain, Europe) and internal ones (the different political sectors in Basque Country). Urbanism "is a very good protocol to use to change public image and, hopefully, political debate. Urbanism and its openness is the permanent contradiction of hard-line nationalism, which seeks to split people, civil society, and cities" (Interview: Victor Urrutia, February 23, $\left.2004^{14}\right)$

Despite lingering, although lessening, political violence by extremist Basque nationalists, Basque Country is characterized by its movement toward peace. The threat of political violence that hovers over contemporary Basque Country would argue against such an optimistic classification. Yet, the spawning of new state-regional-local intergovernmental cooperative ventures that transcend differences on nationalistic issues and the prioritization of functional over political issues is indicative of progress toward more workable governance amidst nationalism. The extent of innovation, dynamism, and engagement by urbanism in the Basque Country suggests that urban interventions may be out-pacing the rate of political progress in the region overall. In addition, despite political violence, the robust regional autonomy that exists in Basque Country (vis-à-vis the Spanish state) recognizes and supports Basque group identity and appears responsive to the aspirations of more mainstream Basque nationalist groups. Further, at the local and regional levels, there is political inclusion of Basque moderate nationalists and nonnationalists, who share the governance of Basque cities and engage in their collective enterprises.

\section{Sarajevo (2003)}

The capacity of urban policymakers and planners in the city of Sarajevo to accommodate Bosnian Muslim, Serb, and Croat nationalistic differences has been constrained and quartered - ironically, by the well-intentioned diplomatic agreements that successfully stopped the shooting wars. The ability of urbanism and local policy to reinstate Sarajevo's multicultural environment in the future has been constrained by the 1995 Dayton peace accord, which provided little space for the city to integrate and assimilate peoples. Instead, in Sarajevo and Bosnia, the drawing of political boundaries has accommodated and compartmentalized ethnic differences and reinforced war-hardened nationalistic group iden-

\footnotetext{
${ }^{14}$ Professor, Sociology, University of Pais Vasco, Bilbao.
} 
tities geographically. Diplomatic agreements rejected international administration of the urban area as an option, drew Serb entity boundaries just outside its city boundary to the east, created Muslim-majority Cantonal boundaries on the Federation side that now engulf it, and have restricted the city's spatial reach [66]. The effect of such ethnic demarcation and gerrymandering has been to tighten the screws on Sarajevo city's ability to act as an opportunity space for multiculturalism and mixing. Despite past international and local efforts to assure cross-ethnic shared political power in the city, the post-war city, when all negotiations were done, was structured in ways that obstructs its ability to be an agent for genuine political inclusion of all three nationality groups. Political boundaries created by the Bosnian peace agreement initiated processes that relegated Serbs and Croats to the sidelines of Sarajevo city governance.

As the largest and capital city of Bosnia-Herzegovina, Sarajevo provides an important potential foundation upon which to rebuild multiculturalism, and from which to develop viable democratic governance and economic interdependences that could normalize the country. Yet, the Dayton redrawing of political space in Bosnia left little room for cities like Sarajevo to act as societal transformation agents in the future. The city of Sarajevo was crippled in terms of institutional power vis-à-vis its county (Cantonal) government, and is only a "partial" actor amidst continuing strong oversight by the international community (vertical differentiation of policy). Extensive international intervention has focused on physical reconstruction rather than social rehabilitation. Substantial money from the EU, and from member states, has led to extensive and visible progress in physically redeveloping the city. However, without social reconciliation, Sarajevo may be increasingly physically rebuilt but the population will be ethnically sorted, and psychologically torn and traumatized.

Political violence is not present in Sarajevo, having been exhausted for now by the horrific violence of the Bosnian war (1992-1995). In this sense, Sarajevo is characterized by movement toward peace. Urban policymakers in Sarajevo can deal more with the normal problems of a big city than explicitly ethnic and nationalistic ones; it doesn't experience ethnic gridlock nor is it hampered by physical partitions. Greater attention can be paid to managing the microgeographies of ethnic minorities in order to sustain them in the urban sphere, although progress in Sarajevo on issues of ethnic mixing has been limited. Sarajevo planners also have more opportunities to explore ways of functionally transcending ethnic boundaries. Yet, the city's relative manageability constitutes a moral dilemma because its movement toward peace is likely facilitated by its relative ethnic homogenization since the war (80 percent Bosniak Muslim majority compared to a pre-war mix of $40 \%$ Muslim, 30\% Bosnian Serb, and $20 \%$ Bosnian Croat). The implications of this judgmentthat ethnic homogenization promotes urban stability-are troubling for those that wish to advance peace-building in an urban environment. Any increase in the manageability of urban governance, such as in Sarajevo, that results due to the ethnic homogenization of a city's population may likely be sidestepping the larger society's need to genuinely accommodate different groups in a space of shared governance.

\section{Mostar (2004)}

Urbanism has been unable to move the city and its larger region beyond a status of simple suspension of overt conflict between Bosniak Muslims and Croats. Instead, the urban capacity to foster tolerance has been stopped dead in its tracks and captured by ethnic and nationalist dynamics metamorphosed from wartime. Urbanism and urban governance in postwar Mostar have been the primary means by which war profiteers have solidified their power and reinforced nationalist divisions in the urban area. War by means other than overt fighting has been carried out in Mostar for 10 years after the open hostilities of 1992-1994. These other means - parallel institutions, demographic manipulation, obstruction of citywide integrative mechanisms, and corruption of public power for private and ethnicized gain - have brutalized the city and its collective sphere.

Despite notable and direct involvement by the international community in some facets of Mostar's management and its aspirations to unify the post-war city, the 10 years of institutional and political division of post-war Mostar have hardened group identity antagonisms between the two sides, and have stimulated and cemented greater inter-group economic, religious, and psychological differences. The ethnically fragmented local government structure allowed by Bosnian peace agreements created local domains of politically exclusive power, and has created a divided Mostar possibly beyond reconciliation. In the six "city-municipalities" all with dominant Croat or Muslim majorities - partisan urban policies have been dominant as political connections and motivations have driven development rather than sound planning and development policy. Both the Croat and Muslim municipalities withheld power and authority from the central city administration and ethnically carved up the urban area into a "political space" of antagonistic territorial control strategies (Interview: Zoran Bosnjak, May 11, 2004 ${ }^{15}$ ). Parallelism and division in Mostar are at an absurd level as the six ethnic municipalities bent many normal functions of local government to achieve group-specific, not citywide, goals. Public services that should be integrated citywide ranging from electricity and water supply to education and urban planning - have become ethnicized and fragmented.

A central plank of the international community's urban strategy in postwar Mostar represents both the promise and pitfalls of neutral planning and spatial buffering as means of reconstituting a city of extreme division. Approximately 1 mile long and one-half mile wide, a "central zone" in the traditional commercial and tourist center of the city was to be administered by an ethnically balanced city council and administration. Consisting of a common strip of land along the former war confrontation line, the central zone was to act immediately as a spatial buffer between the two sides. Over time, through appropriate development, the central zone would grow like a seed and demonstrate that cross-ethnic activities could resume, first within the zone, and then hopefully in larger swatches of urban space within the "ethnic" municipalities. In practice, however, the same forces that captured the six municipalities for ethnic gain also were able insidiously to warp and dismantle the integrative goals of the central zone. The district became in the early days a target of

\footnotetext{
${ }^{15}$ Architect, Urban Planning Department, City of Mostar
} 
ethnic territorial ambitions and remained that way for ten years.

Ten years after war, Mostar was not psychologically far from open conflict and existed in a suspended state of nonviolent ethnic division. Genuine movements toward multinational peace have not yet taken place and Croats and Bosniaks have institutionally constructed and lived in parallel words that further cement and reinforce ethnic fragmentation. Urban policymakers (both international community and indigenous) did not succeed in the first ten post-war years to create urban conditions that enable tolerance, openness, and genuine democracy. Differentiation across urban space in urban policy and governance approach appears as a particularly damaging characteristic of peace-building in Mostar. There existed a lack of full citywide areal coverage for policies aimed at directing post-war land development toward collective, cross-ethnic ends. An area cordoned off for neutral land use and to be managed by a power-sharing city council contrasted greatly with the six ethnically-pure municipalities that engaged in partisan urbanism in the remaining, and larger, parts of the urban area ${ }^{16}$.

\section{CONCLUSION}

Through discussion of theoretical and methodological issues and brief portrayals of cases study findings, this article has illustrated the extremely complex set of ideas and observations that can help urban analysts and planners to structure their own information and knowledge about contested cities. The use of a focused analytic lens and set of inquiries can provide comparative urban scholarship with both greater understanding of specific issues within a particular polarized city and an increased ability to make generalizations about urban policymaking and governance across an array of such cities. Sensitive construction of theoretical and conceptual categories and scales both informs and challenges scholarly investigators. Conceptualization guides research in terms of what to look for during field study; grounded place-based research, in turn, helps us understand both the accuracies and limits of our theoretical approaches.

Field research based local case study analysis of nationalistic conflict addresses an inherent bias in the study of political conflict toward state-level and international factors. A focus on urban policy interventions that confront local intergroup conflict enables a level of grounded specificity not found in studies of national-level constitutional and political reform (such as found in [40, 67-71). It facilitates a finertuned analysis of the practical, on-the-ground dimensions of building peace, and encourages scholars and practitioners to consider how urban peace building can supplement or even catalyze national peace making.

Extreme circumstances such as found in deeply polarized cities can reveal ordinary truths about the capacity and limitations of urbanism and local governance. Unsettled urban contexts illuminate the basic relationships between urban policy and political power far better than in more mature, settled contexts when these relationships become obfuscated

\footnotetext{
${ }^{16}$ Frustrated with the stunted progress of public authority in fragmented Mostar, the lead international representative for Bosnia imposed by unilateral decree the political unification of the city and city-municipalities effective March 2004.
}

and of greater complexity. In some respects, cities that have gone through major societal disruptions and transformations may be said to be outlier cases. Far from being extraneous to the study of contemporary urbanity, however, polarized cities are central to broader debates about urbanism, democracy, and cultural diversity precisely because inter-group challenges in polarized cities are so fundamental to their future quality of existence. Lessons from these traumatized cities have wide relevance in today's urban world. Indeed, the ethnic fracturing of many cities in North America and Western Europe owing to changing demographics, cultural radicalization, and migration creates situations of 'public interest' fragility and cleavage similar to my case studies. The study of grassroots peace building and creative policy approaches in difficult and contested cities seeks to provide guidance to the many policymakers and professionals across the urban world that increasingly are struggling to address multiple publics and contrasting cultural views of city life and function.

Carefully constructed comparative research on troubled cities allows us to identify key dimensions that display variation across settings and increases our understanding of what is unique and what is universal in a particular city. In policy terms, such comparative studies can isolate key enabling and blocking factors that influence urban co-existence and stability. Because there exists high and urgent policy salience of comparative work on conflicted cities, dissemination strategies should be incorporated into these research projects that target audiences beyond the academic community and produce policy-relevant condensed reports and summary memoranda geared toward practitioners and their professional networks.

\section{REFERENCES}

[1] Bollens SA. Urban peace-building in divided societies: Belfast and Johannesburg. Boulder, CO and Oxford, UK: Westview Press 1999.

[2] Bollens SA. On narrow ground: Urban policy and conflict in Jerusalem and Belfast. Albany, NY: State University of New York Press 2000.

[3] Bollens SA. Cities, nationalism, and democratization. Oxford and New York: Routledge 2007.

[4] Moser C, McIlwaine C. Encounters with violence in Latin America: Urban poor perceptions from Columbia and Guatemala. London: Routledge 2004.

[5] Caldeira T. City of walls: Crime, segregation, and citizenship in Sao Paulo. Berkeley: University of California Press 2000.

[6] Schneider J, Susser I, Eds. Wounded cities: Destruction and reconstruction in a globalized world. Oxford: Berg 2003.

[7] George AL, Smoke R. Deterrence in American foreign policy: Theory and practice. New York: Columbia 1974.

[8] Schnabel A. One size fits all? Focused comparison and policyrelevant research on violently divided societies. In: Smyth M, Robinson G, Eds. Researching violently divided societies: Ethical and methodological issues. London: Pluto 2001; pp. 193-206.

[9] Hantrais L. Contextualization in cross-national comparative research. Int J Soc Res Methodol 1999; 2(2): 93-108.

[10] Heidenheimer AJ, Heclo H, Adams CT. Comparative public policy: The politics of social choice in America, Europe, and Japan. New York: St. Martin's 1990.

[11] Masser I. Some methodological considerations. In: Masser I, Williams R, Eds. Learning from other countries: The cross-national dimension in urban policy-making. Norwich, UK: Geo 1986.

[12] Cropper SA. Theory and strategy in the study of planning processes-The uses of the case study. Environ Plan B 1982; 9: 341-57.

[13] Alterman R. A transatlantic view of planning education and profes sional practice. J Plan Edu Res 1992; 12(1): 39-54. 
[14] Lincoln YS, Guba EG. Naturalistic inquiry. London: Sage 1985.

[15] Smyth M, Darby J. Does research make any difference? The case of Northern Ireland. In: Smyth, M, Robinson G, Eds. Researching violently divided societies: Ethical and methodological issues. London: Pluto 2001; pp. 34-54.

[16] Darby J, MacGinty R. The management of peace processes. London: MacMillan 2000

[17] Hepburn A. Contested cities in the modern west. London: Palgrave MacMillan 2000.

[18] Ben-Porat G. Global liberalism, local populism: Peace and conflict in Israel/Palestine and Northern Ireland. Syracuse, NY: Syracuse Press 2006.

[19] Oberschall A. Conflict and peace building in divided societies: Responses to ethnic violence. London: Routledge 2007.

[20] Charlesworth, E. Architects without frontiers: War, reconstruction, and design responsibility. Amsterdam: Elsevier 2006.

[21] Agostini G, Chianese F, French W, Sasdhu A. Understanding the processes of urban violence: An analytical framework. Crisis States Research Centre, London School of Economics, London 2007.

[22] Gidron B, Katz SN, Hasenfeld Y. Mobilizing for peace: Conflict resolution in Northern Ireland, South Africa, and Israel/Palestine. New York: Oxford 2002.

[23] Kerr M. Imposing power-sharing: Conflict and coexistence in Northern Ireland and Lebanon. Dublin: Irish Academic Press 2006.

[24] Pullan W. Conflict in cities and the contested state. Economic and Social Research Council grant RES-060-25-0015. ESRC, Wiltshire, UK 2007.

[25] Rotberg RI, Ed. When states fail: Causes and consequences. Princeton, NJ: Princeton University Press 2004.

[26] Horowitz DL. The deadly ethnic riot. Berkeley: University of California 2003.

[27] Roeder PG, Rothchild D, Eds. Sustainable peace: Power and democracy after civil wars. Ithaca, NY: Cornell University Press 2005.

[28] Bottger A, Strobl R. Potentials and limits of qualitative methods for research on violence. In: Heitmeyer W, Hagan J, Eds. International handbook of violence research. Dordrecht, Netherlands: Kluwer 2003; pp. 1203-18.

[29] Bilski R, Galnoor I. Ideologies and values in national planning. In: Bilski R, Galnoor I, Inbar D, Manor Y, Sheffer G, Eds. Can planning replace politics? The Israeli experience. The Hague: Martinus Nijhoff 1980; pp. 77-98

[30] Benvenisti MS. Conflicts and contradictions. New York: Villard Books 1986.

[31] Collier D, Mahoney J. Insights and Pitfalls: Selection bias in qualitative research. World Polit 1996; 49(1): 56-91.

[32] Wright G, Rabinow P. Spatialization of power: A discussion of the work of Michel Foucault. Skyline 1982; 14: 13-14.

[33] Gurr TR. Why minorities rebel: A global analysis of communal mobilization and conflict since 1945. Int Polit Sci Rev 1993; 14 (1): 161-201.

[34] Stanovcic V. Problems and options in institutionalizing ethnic relations. Int Polit Sci Rev 1992; 13(4): 359-79.

[35] Burton JW, Ed. Conflict: Human needs theory. New York: St. Martin's Press 1990.

[36] Murphy AB. Territorial policies in multiethnic states. Geogr Rev 1989; 79: 410-21.

[37] Sack R. Human territoriality: Its theory and history. Cambridge: Cambridge University Press 1986

[38] Yiftachel O. Planning a mixed region in Israel: The political geography of Arab-Jewish relations in the Galilee. Aldershot: Avebury 1992.

[39] Coakley J. Introduction: The territorial management of ethnic conflict. In: Coakley J, Ed. The territorial management of ethnic conflict. London: Frank Cass 1993; pp. 1-22.

[40] O'Leary B, McGarry J. Regulating nations and ethnic communities. In: Breton A, Galeotti G, Salmon P, Wintrobe R, Eds. Nationalism and rationality. Cambridge: Cambridge University Press 1995; pp. 245-89.
[41] Weitzer R. Transforming settler states: Communal conflict and internal security in Northern Ireland and Zimbabwe. Berkeley: University of California 1990

[42] Friedman S. An unlikely utopia: State and civil society in South Africa. Politikon: South Afr J Polit Stud 1991; 9(1): 5-19.

[43] Partrick N. Democracy under limited autonomy. News from within 1994; 10(9): 21-24. Jerusalem: Alternative Information Center (newsletter).

[44] Neill W. Urban planning and cultural identity. London: Routledge 2004.

[45] Le Gales P. European cities: Social conflicts and governance. Oxford: Oxford University Press 2002.

[46] United Nations Development Programme. Human development report 2002, deepening democracy in a fragmented world. New York: Oxford University Press 2002.

[47] Savitch H. Cities in a time of terror: Space, territory, and loca resilience. Armonk, N.Y.: M.E. Sharpe 2008.

[48] Savitch H, Ardashev G. Does terror have an urban future? Urban Stud 2001; 38(13): 2515-33

[49] Vision of Humanity. Global peace index. [Retrieved 2008 April 3]. Available from: http://www.visionofhumanity.org /gpi/index.php

[50] Freedom House. Countries at a crossroads. [Retrieved 2008 March 1]. Available from: http://www.freedomhouse.org/

[51] Esty DC, Goldstone JA, Gurr TR. State failure task force report: Phase II findings. Science Applications International Corporation, McLean, VA 1998

[52] Goldstone JA, Gurr TR, Harff B. State failure task force report: Phase III findings. Science Applications International Corporation, McLean, VA 2000.

[53] Putzel James. Overview: Crisis states programme. Crisis States Research Programme, London 2003

[54] Hantrais L, Mangen S, Eds. Cross-national research methods in the social sciences. London: Pinter 1996.

[55] B'Tselem. A policy of discrimination: Land expropriation, planning, and building in East Jerusalem. B'Tselem-The Israeli Information Center for Human Rights in the Occupied Territories, Jerusalem 1995.

[56] Kaminker S. East Jerusalem: A case study in political planning. Palestine-Israel J 1995; 2(2): 59-66.

[57] Ashkenasi A. Opinion trends among Jerusalem Palestinians. Leonard Davis Institute of International Relations, Hebrew University, Jerusalem 1990.

[58] Cunningham C, Byrne S. Peacebuilding in Belfast: Urban governance in polarized societies. Intl J World Peace 2006; 23(1): 41-73.

[59] Department of the Environment for Northern Ireland. Belfast urban area plan 2001 (draft). Her Majesty's Stationery Office (HMSO), Belfast 1987.

[60] Smith DJ, Chambers D. Equality and inequality in Northern Ireland 4: Public housing. Policy Studies Institute, London 1989.

[61] Knox C, Carmichael P. Bureau shuffling? The review of public administration in Northern Ireland. Public Administration 2006; 84(4): 941-65.

[62] Byrne S, Irvin C. A shared common sense: Perceptions of the material effects and impacts of economic growth in Northern Ireland. Civil Wars 2002; 5(1): 55-86.

[63] Sisk TD, Stefes C. Power sharing as an interim step in peace building: Lessons from South Africa. In: Roeder, PG, Rothchild D, Eds. Sustainable peace: Power and democracy after civil wars. Ithaca: Cornell University Press 2005; pp. 293-317.

[64] Metropolitan Corporation of Barcelona. The general metropolitan plan for Barcelona. Author, Barcelona 1976

[65] Rodriguez A, Martinez E, Guenaga G. Uneven redevelopment: New urban policies and socio-spatial fragmentation in metropolitan Bilbao. Eur Urban Reg Stud 2001; 8(2): 161-78.

[66] Burg, SL, Shoup PS. The war in Bosnia-Herzegovina: Ethnic conflict and international intervention. Armonk, NY: M.E. Sharpe 1999

[67] G-Gagnon A, Tully J. Multinational democracies. Cambridge: Cambridge University Press 2001. 
[68] Lapidoth R. Autonomy: Flexible solutions to ethnic conflicts. Washington D.C.: United States Institute of Peace 1996.

[69] Newman S. Ethnoregional conflict in democracies-mostly ballots, rarely bullets. Westport, CT: Greenwood Press 1996.
[70] Lijphart A. The politics of accommodation: Pluralism and democracy in the Netherlands. Berkeley, CA: University of California Press 1968.

[71] Nordlinger EA. Conflict regulation in divided societies. Boston: Center for International Affairs, Harvard University 1972.

(C) Scott A. Bollens; Licensee Bentham Open.

This is an open access article licensed under the terms of the Creative Commons Attribution Non-Commercial License (http://creativecommons.org/licenses/by$\mathrm{nc} / 3.0 /$ ) which permits unrestricted, non-commercial use, distribution and reproduction in any medium, provided the work is properly cited. 